\title{
25. Estimation of Industrial and Household Water Use by using Input-output table and questionnaire survey in Lower Chao Phraya River Basin, Thailand
}

\author{
Pongsak SUTTINON, ${ }^{1}$ and Nasu SEIGO ${ }^{2}$
}

\begin{abstract}
In this paper, industrial and household water use was surveyed and analyzed in Lower Chao Phraya River Basin. Water use unit analysis is a main initial part of water demand management model. Questionnaire, interview and field survey were selected to collect data. Three main topics are concentrated in this survey; (1) water use and source, (2) water use in each process, and (3) water situation in the future. At 95 percentages significant level, 400 samples of each industrial and household questionnaires is needed for analyzing. Industrial water unit use by International Standard Industrial Classification (ISIC) code in unit of cubic meter per million Thai baht was analyzed from surveyed water use data with monetary term of intermediate transaction from analyzed input-output table. In study area, average industrial water use unit is $2.2 \mathrm{~m}^{3} / \mathrm{d} / \mathrm{M}$.THB. The main water users are textile, chemical, and food product. Household water use unit in Bangkok with 346 liter per capita per day is the highest in study area because of high water consumed activities from higher daily life styles.
\end{abstract}

Keyword: industrial and household water demand management, input-output table, questionnaire survey

\section{Introduction}

Lower Chao Phraya River Basin (LCPRB) is one of the important areas of development in economic and industrial sector in Thailand. Thai government concentrates to develop industrial activities by declared industrial cluster strategy master plan and free trade agreements or FTAs with other countries. An increase in demand of output resulted from declared policies is likely to cause a rise in need of infrastructure especially water in production and utility process. Not only higher industrial water need, but household water use is highly growing also because of rapid population growth and changed life style from higher GDP per capita. However, water use unit analysis is the initial important part of water demand management. From that reason, industrial and household questionnaire survey was operated in 2006 to collect data in study area.

NASU Laboratory, Department of Infrastructure Systems Engineering, Kochi University of Technology, Tosayamada Cho, Kochi, Japan, 782-8502; PH (+81)-887-57-2232; FAX (+81)-887-57-2811; email ${ }^{1}$ : 096408z@gs.kochi-tech.ac.jp, email ${ }^{2}$ : nasu.seigo@kochi-tech.ac.jp 
The objective of this paper is to analyze industrial and household unit water use, source and water need in each production activity.

\section{Methodology}

The schematic diagram of industrial water demand and management model developed by using GAMs language is shown in Figure 1. For household sector, the model structure is similar to industrial part but population model is used instead of input-output model. The model was divided into four parts; water demand, water supply, integrated water management model, and Strategic decision making with uncertainly for water infrastructure development (SUTTINON, P., 2006, 2007(1,2)).

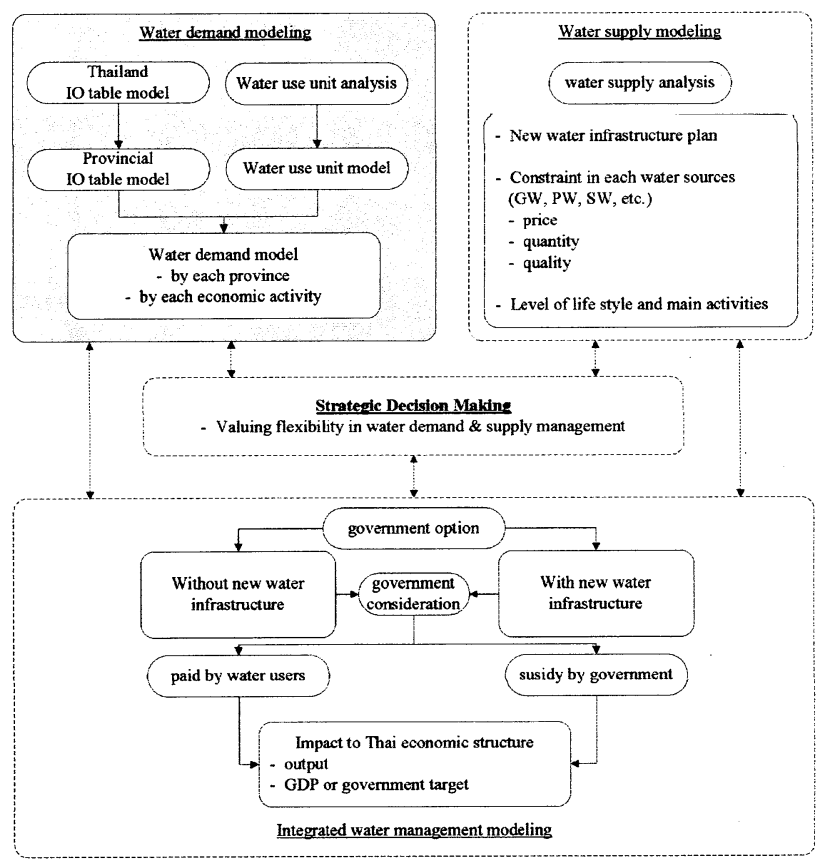

Figure 1. Schematic diagram.

Water use unit analysis is the main activities in the first step of water demand management model. Firstly, water demand in each province and industrial activity was calculated from intermediate transactions of input-output (IO) table model and water use unit analysis. The objective of using IO table model is to analyze changing economic structures and input-output flows from declared governmental strategies. Water use unit per monetary terms of product was calculated from the collection data from government agencies and questionnaire survey by Kochi University of Technology in 2006. For household sector, water use per capita per day was analyzed from each activity in daily life of citizen in study area.

Firstly, number of questionnaire sample was designed by statistical analysis with 95 percentage significant level. 400 samples of each industrial and household questionnaire 
were needed to analyze. However, sending questionnaires were 2,000 samples in each sector because of 20 percentages of response rates. The number of sample in each province was weighted again with number and density of factories and population in 7 provinces. Figure 2 shows the map of Thailand and scatter of questionnaire survey in industrial and household survey. Bangkok is the main target of this survey because high density of industrial activities and population.

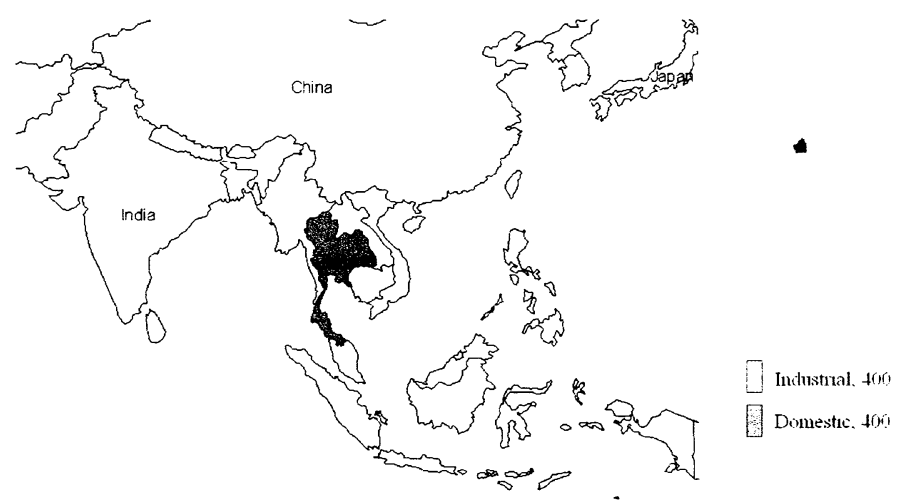

(a.) Map of Thailand

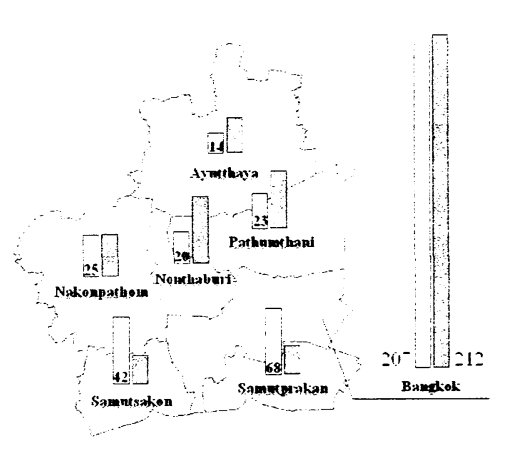

(b.) Map of Study area

Figure 2. Study area and scatter of factories.

\section{Industrial questionnaire survey}

There are 3 main topics in this survey. The first is water use and source. Monthly water use in average and maximum rate, water price, initial cost for investment, problem, and solution are collected in this topic. Water sources consist of tap water, groundwater, and surface water (pond, river, irrigation canal or natural canal).

The second topic is detail of water use in each source and activity such as production (raw material or washing), utility (boiler or cooling system), and office or dormitory. The special detail such as treated water before using will be collected in this topic.

The last part is concentrated in effect from pipe water, water saving policy in factory, trend of production capacity \& use, water saving policy by government, and effect from pricing policy. The reason why effect from pipe water was concentrated is because of the problem of changing quality of production from using pipe water in textile, food and beverage factories which are the heavy water consumer in this area. 
From the problem of land subsidence in this study area, Department of Groundwater Resources declared GW use controlling policy to reduce $\mathrm{GW}$ use from maximum pumpage approximately $2.64 \mathrm{Mm}^{3} / \mathrm{d}$ in 1999 to meet permissible yield at 1.25 or $0.63 \mathrm{Mm}^{3} / \mathrm{d}$ for industrial sector (Buapeng, S., 2006). This rapidly decreased GW supply was highly effected to industrial structure of Thailand and target economic output.

From the constraints in study area, not only supply side management should be implemented, but water demand management model in figure 1 is one of the interesting solutions for this area also.

\section{Household questionnaire survey}

There are 3 main topics in this household survey. The questions are as same topic as industrial sector but details are different. In the second part, water use in each activity is collected, for example, the water use, duration, and facility in bathroom, toilet, laundry, cleaning, garden, and kitchen.

The third part is concentrated in changing water source from the past, water use situation, reason to choose pipe water, changing water use with suitable price, and water saving policy.

\section{Results}

Figure 3 shows industrial and household water source and use by process. In study area, groundwater is main part with 61 percentages because main groundwater consumer such as textile, food, and beverage factories are located in this area especially Bangkok, Samut Prakarn, and Samut Sakhon. This high percentage with limited groundwater from declared regulation show conflict between groundwater demand and supply in this area. Production process is the highest water user with 57.6 percentages as shown in figure $3 \mathrm{c}$. One of interesting constraint is limitation of recycled water percentage in production process because of the quality of water used in raw material and process in food and beverage factory type.

For household sector in study area, pipe water is main part with 83.1 percentages. The main user is located in Bangkok and vicinity which is the capital of Thailand. There are two main water agencies in this area; Metropolitan Waterworks Authority (MWA) and Provincial Waterworks Authority (PWA). Service area of MWA is only Bangkok (BKK), Nontaburi 
(NTB), and Samut Prakarn (SPK) with 81.4 percentages of pipe water use as shown in black area of figure $3 \mathrm{e}$.

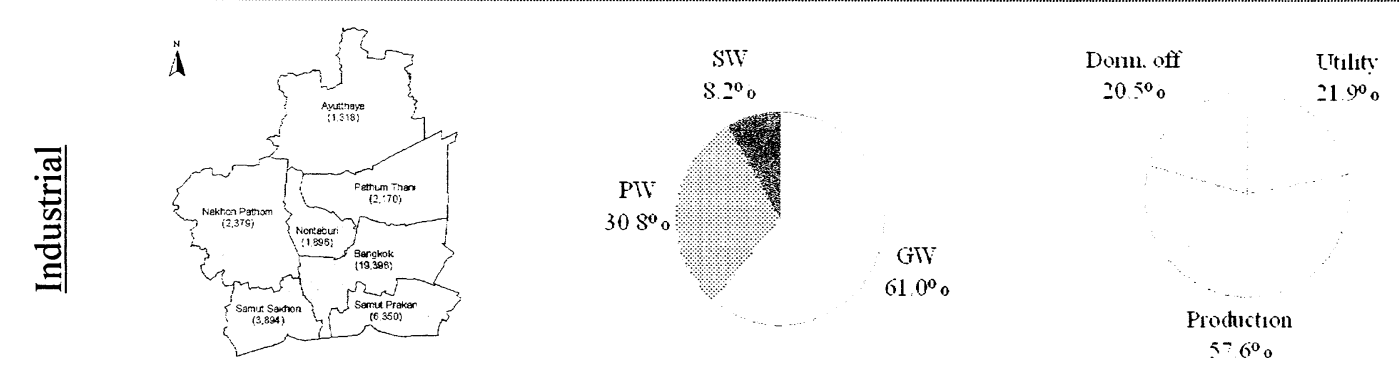

(a) Scatter of factory

(b) Water source

(c) Water use by process

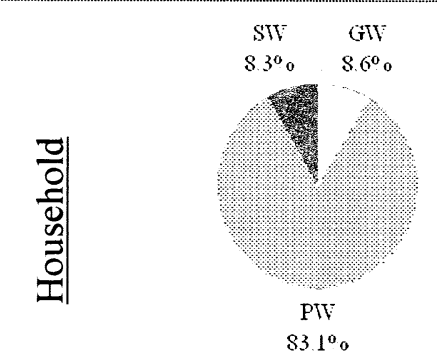

(d) Water source
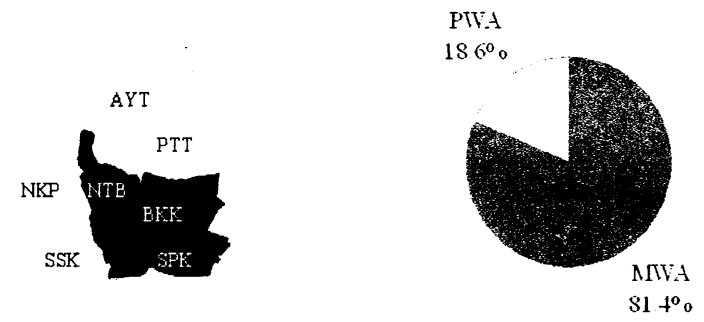

(e) Service area

(f) Water use by agency

Figure 3. Industrial and household water source and use by process

Table 1 shows one example of water use unit and water demand classified by ISIC code in study area. Water use unit was analyzed from water use data of questionnaire survey and input-output table model. The heavy water consumers in this area are textile, chemical, and food and beverage product. This analyzed is important for demand management model in the next step. Changing structure of water use with water saving policy can calculated by using this table with input-output table model.

Table 2 shows an example of household water use in case of Bangkok. Main activity is bathing with $116 \mathrm{lpcd}$. In the next step, this data will be used as base data to calculate changing unit water use with changing life style. 
Table 1 Examples of output and water demand classified by ISIC code

\begin{tabular}{|c|c|c|c|c|c|c|}
\hline \multicolumn{3}{|r|}{ ISIC code } & \multirow{2}{*}{$\begin{array}{c}\text { Water unit } \\
\text { Cum } / \mathrm{d} / 10^{6} \text { Baht }\end{array}$} & \multirow{2}{*}{$\begin{array}{c}\text { Real output } \\
10^{6} \text { Baht }\end{array}$} & \multicolumn{2}{|c|}{ Water demand } \\
\hline \multicolumn{2}{|c|}{ Code* } & Description & & & Cum/day & $\mathrm{MCM} /$ year \\
\hline A & 01 & Agriculture and service activities & 25.1 & 638 & 16,024 & 6 \\
\hline $\mathrm{C}$ & 14 & Other mining and quarrying & 30.0 & 241 & 7,241 & 3 \\
\hline \multirow[t]{3}{*}{$\mathrm{D}$} & 15 & Food products and beverages & 1.1 & 169,605 & 191,673 & 70 \\
\hline & 16 & Tobacco products & 0.5 & 15,035 & 7,523 & 3 \\
\hline & 17 & Textiles & 6.3 & 72,708 & 455,690 & 166 \\
\hline & & Study area & 2.2 & 830,986 & $1,844,176$ & 673 \\
\hline
\end{tabular}

Note: * ISIC code: A Agriculture, hunting and forestry, $\mathrm{C}=$ Mining and quarrying, $\mathrm{D}=$ Manufacturing,

Table 2 Examples of household water use, (Liter per capita per day, LPCD)

\begin{tabular}{cccccccc}
\hline Activities & Bathing & Toilet & Laundry & Cleaning & Garden & Cooking & Total \\
\hline Lpcd & 116 & 16 & 26 & 38 & 87 & 61 & 346 \\
\hline
\end{tabular}

\section{Conclusion}

Industrial and household water use unit in each activity was analyzed by using water use data from questionnaire, interview, field survey, and output data from input-output table model for industrial sector. This analyzed data will be the useful base information for changing structure of water use, economic, and population from declared governmental strategy and master plan in the future.

\section{References}

Buapeng, S., Lorphensri, O., and Ladawadee, A. (2006). "Groundwater Situation and Land Subsidence Mitigation in Bangkok and Its Vicinity", The 3rd APHW Conference, October 16-18, 2006, Thailand.

Suttinon, P., and Seigo, N. (2007). "Industrial Water Demand Prediction Model by Using Input-Output Table: The Case of Industrial Strategy of Thailand and Impacts from Pricing Policy" The World Environmental \& Water Resources Congress 2007, May 15-19, 2007, Tampa, Florida.

Suttinon, P., and Seigo, N. (2007). "Industrial Water Demand Prediction Model: The Case of Changing Industrial Market Share from Free Trade Agreements", The International Symposiums on Social Management Systems (ISMS2007), 9-11 March 2007, CHINA.

Suttinon, P., and Seigo, N. (2006). "Industrial Water Demand Prediction Model: The Case of Thailand Industrial Cluster Strategy" The 3rd APHW Conference, October 16-18, 2006, Thailand. 